\title{
Efficient Separation of Five Flavonoids from Oxytropis falcata Bunge by High- Speed Counter-Current Chromatography and their Anticancer Activity
}

\author{
Chen Chen ${ }^{1 *}$, Fengqin Liu ${ }^{1}$, Jingyang Zhao ${ }^{1}$, Tao Chen ${ }^{1}$, Yulin $\mathrm{Li}^{1}$ and Dejun Zhang ${ }^{2 * *}$ \\ 'Key Laboratory of Tibetan Medicine Pharmacology and Safety Evaluation, Northwest Institute of Plateau Biology, \\ Chinese Academy of Sciences, Xining, P. R. China \\ ${ }^{2}$ State Key Laboratory of Plateau Ecology and Agriculture, Qinghai University, Xining 810016, P. R. China
}

Received: 10 June 2019; accepted: 13 Aug 2019

\begin{abstract}
Oxytropis falcata Bunge, known as the "king of herbs" in Tibetan medicine, is used for treatment of hyperpyrexia, pain, wounds, inflammation, and anthrax. However, it is difficult to efficiently isolate compounds with high purity from $O$. falcata because of the complexity of traditional Tibetan medicines. In this study, the $80 \%$ ethanol elution fraction from extract by AB-8 macroporous resin column chromatography was demonstrated to have anticancer activity on human hepatoma SMMC-7721 cells in vitro. Then, a high-speed counter-current chromatography (HSCCC) method was successfully established for separation of compounds by using hexane-ethyl acetate-methanol-water (10:4:10:10, v/v/v/v) as the solvent system. Five flavonoids (7-hydroxyflavonone [1], 5,7-dihydroxy-4'methoxy flavonol [2], 5,7-dihydroxyflavanone [3], 2',4'-dihydroxychalcone [4], and 2',4'-dihydroxydihydrochalcone [5]) were obtained in one-step separation with purities of $97.7 \%, 98.1 \%, 98.3 \%, 99.0 \%$, and $98.3 \%$, respectively. Finally, anticancer activities against the growth of SMMC-7721 cells of 5 flavonoids were confirmed. The $\mathrm{IC}_{50}$ values of the separated compounds were $213.45 \mu \mathrm{g} / \mathrm{mL}, 197.74 \mu \mathrm{g} / \mathrm{mL}, 375.16 \mu \mathrm{g} / \mathrm{mL}, 17.44 \mu \mathrm{g} / \mathrm{mL}$, and $136.83 \mathrm{\mu g} / \mathrm{mL}$ in $24 \mathrm{~h}$, respectively. The present study provided a basis for further development and utilization of this medicinal herb as a source of a new potential anticancer agent.
\end{abstract}

Keywords: Oxytropis falcata Bunge, high-speed counter-current chromatography, flavonoids

\section{Introduction}

Oxytropis falcata Bunge, which belongs to the Leguminosae family, locally known as the "king of herbs" in Tibetan medicine, grows naturally in the northwest part of China at an altitude of $2700-4300 \mathrm{~m}$ and has been widely applied in Tibetan and Mongolian medicine for the treatment of ailments such as influenza, hyperpyrexia, pain, wounds, hemorrhage, inflammation, and anthrax [1]. The extracts of $O$. falcata have been reported to exhibit a wide range of biological activities, such as anticancer, antioxidant, and anti-inflammatory, among others [2-5]. In recent years, more and more attention has been drawn to the fact that $O$. falcata has stronger anticancer activity. Yang et al. investigated that essential oil and total flavonoids of $\mathrm{O}$. falcata showed antiproliferative activity on SMMC-7721 through down-regulating secretion and expression of MMP-2 in cells [6]. Yang et al. reported that total flavonoid of $\mathrm{O}$. falcata is a pro-apoptotic agent for hepatic cancer cells via its modulation of Bcl-2 /Bax balance [7]. Chen et al. investigated that total flavonoids of O. falcata influence mitochondrial apoptosis pathway [8]. However, the pharmacological activity measurements were conducted on complex extracts, and what kind of compounds and how each of these compounds contributed to the biological effects are not clearly understood. Therefore, it is very necessary to isolate the active compounds from $O$. falcata.
Previous studies have shown that the major phytochemicals in O. falcata are flavonoids, alkaloids, and triterpenoids $[9,10]$. With regard to the methods available for the separation of compounds from $O$. falcata, silica and gel chromatography methods are the two classical methods that were applied. However, these two conventional strategies are time-consuming, labor-intensive, and expensive process. Recently, preparative high-performance liquid chromatography (prep-HPLC) has been used for separating compounds from O. falcata [11]. However, prep-HPLC has low sample loading capacity and low recovery potential.

High-speed counter-current chromatography (HSCCC) is an optimal choice, which is a continuous liquid-liquid partition chromatography between two immiscible liquid phases without a support matrix. Compared to conventional column chromatography and pre-HPLC, HSCCC has advantages of eliminating irreversible adsorption, lowering the risk of sample denaturation, increasing total sample recovery, raising load capacity, and lowering the cost [12]. HSCCC has been successfully applied to purify many bioactive compounds from natural products [13-15].

To the best of our knowledge, no article has been successfully published about the use of HSCCC for separation and purification of anticancer compounds from $O$. falcata. In this article, 5 flavonoids with high purities were obtained by HSCCC for the first time, and the anticancer activities of these 5 flavonoids were studied. The structures of the 5 flavonoids are shown in Figure 1.

\section{Experimental}

Chemicals and Materials. All solvents that were used in HSCCC separation were of analytical grade. 3-(4,5- 
<smiles>O=C1CC(c2ccccc2)Oc2cc(O)ccc21</smiles><smiles>COc1ccc(-c2oc3cc(O)cc(O)c3c(=O)c2O)cc1</smiles><smiles>O=C1CC(c2ccccc2)Oc2cc(O)cc(O)c21</smiles><smiles>O=C(/C=C/c1ccccc1)c1ccc(O)cc1O</smiles><smiles>O=C(CCc1ccccc1)c1ccc(O)cc1O</smiles>

Figure 1. Chemical structures of compounds from $O$. falcata (1: 7-hydroxyflavonone, $\mathrm{C}_{15} \mathrm{H}_{10} \mathrm{O}_{4} ; 2$ : 5,7-dihydroxy-4'-methoxy flavonol, $\mathrm{C}_{15} \mathrm{H}_{10} \mathrm{O}_{4} ; 3$ : 5,7-dihydroxyflavanone, $\mathrm{C}_{15} \mathrm{H}_{12} \mathrm{O}_{4} ;$ 4: 2',4'-dihydroxychalcone, $\mathrm{C}_{15} \mathrm{H}_{11} \mathrm{O}_{3} ; \mathbf{5}: 2^{\prime}$, 4'-dihydroxydihydrochalcone, $\mathrm{C}_{15} \mathrm{H}_{13} \mathrm{O}_{3}$ )

Dimethylthiazol-2-yl)-2,5-diphenyltetrazolium bromide (MTT) was purchased from Sigma Chemical Co. (St. Louis, MO, USA). AB-8 macroporous resin was purchased from the Chemical Plant of Nankai University (Tianjing, China).

The whole plant of O. falcata was collected from Qinghai Lake of Qinghai Province, China, in August 2017. The plant was identified by Professor Dejun Zhang (Qinghai University). A voucher herbarium specimen was deposited at Northwest Institute of Plateau Biology (Xining, China) with the voucher number 20180809-O.

Apparatus. The HSCCC system was equipped with 3 polytetrafluoroethylene preparative coils (total volume $=280$ $\mathrm{mL}$ ). The system was equipped with a pump, a UV detector, a constant temperature-circulating implement, a sample loop, and a model N2000 workstation.

HPLC analysis was performed on an Agilent 1200 system (Agilent Technologies Co. Ltd., USA). The Agilent 1200 system was equipped with a pump, a DAD detector, a column thermostat, and an Agilent HPLC workstation.

A Bruker Avance $600 \mathrm{MHz}$ (Bruker, Karlsruhe, Germany) spectrometer was used for the NMR experiments, and tetramethylsilane was used as the internal standard.
Preparation of Crude Sample. The whole fresh plant was air-dried in the shade at room temperature and ground to a fine powder. The dried powder $(1 \mathrm{~kg})$ was extracted with $75 \%$ ethanol under reflux three times ( $2 \mathrm{~h}$ each time). All extracting solution were combined and concentrated. The process produced $210 \mathrm{~g}$ crude extract. The crude extract was then suspended in distilled water and extracted with petroleum ether and ethyl acetate, sequentially, which yielded $48.8 \mathrm{~g}$ of the petroleum ether fraction, $102.4 \mathrm{~g}$ of the ethyl acetate fraction, and $57.8 \mathrm{~g}$ of the water fraction.

The $57.8 \mathrm{~g}$ water fraction was separated by AB- 8 column chromatography $(8 \mathrm{~cm} \times 120 \mathrm{~cm}, 4.0 \mathrm{~kg} \mathrm{AB}-8$ macroporous resin). Ethanol solutions $(20 \%, 40 \%, 60 \%$, and $80 \%)$ were used consecutively to elute the resin until eluent was nearly colorless. All elution fractions were collected for further research, and $7.2 \mathrm{~g} 80 \%$ ethanol fraction was collected. The $80 \%$ fraction was used for HSCCC separation. Figure 2 summarizes the separation process of anticancer compounds from O. falcata.

Determination of Anticancer Activity. The in vitro anticancer activities of the samples on SMMC-7721 were determined by the MTT-based colorimetric method [16].

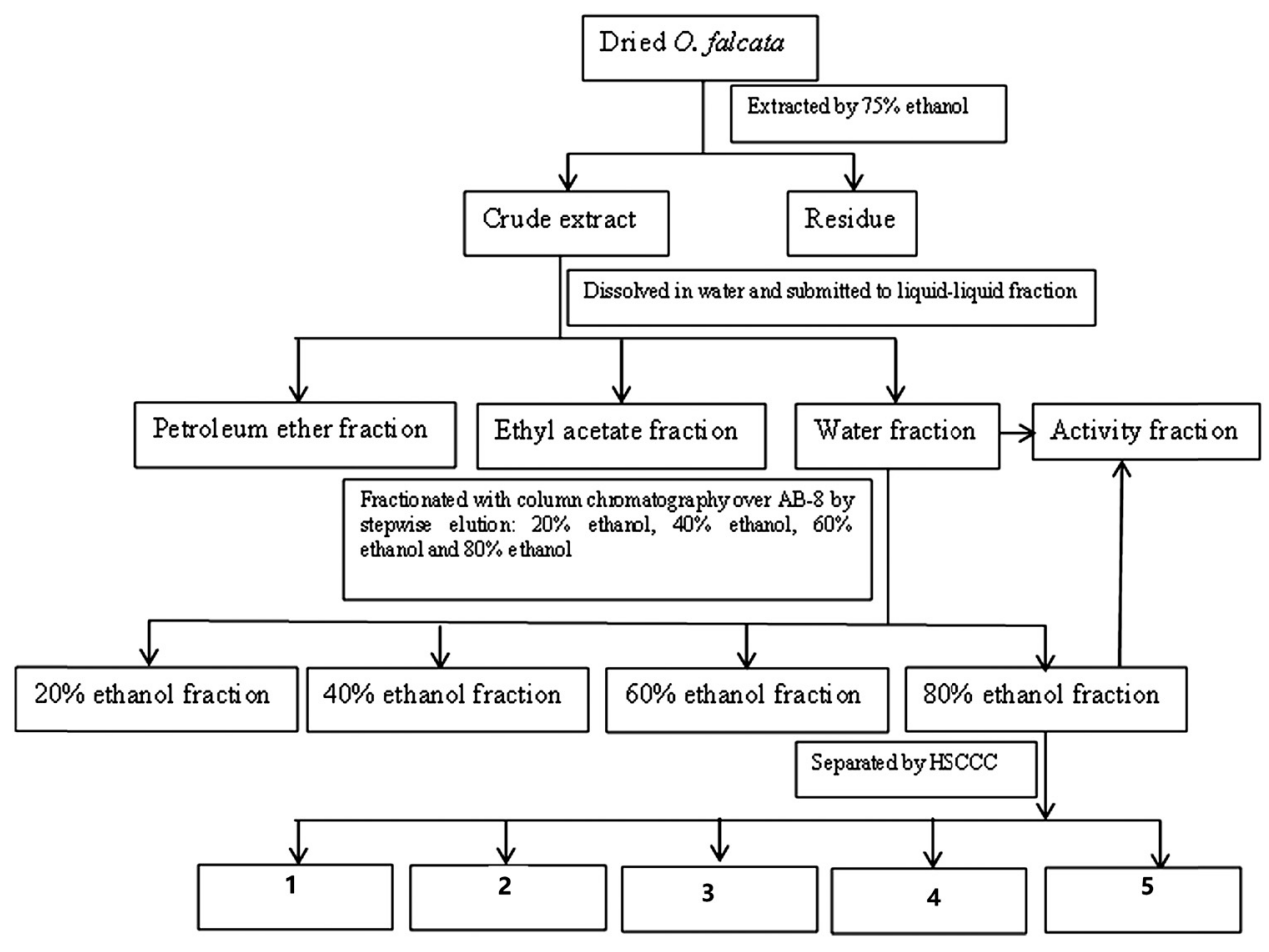

Figure 2. The procedure of screening and preparative isolation of compounds from $O$. falcata (7-hydroxyflavonone 1, 5,7-dihydroxy-4'-methoxy flavonol 2, 5,7-dihydroxyflavanone 3, 2',4'-dihydroxychalcone 4, 2',4'-dihydroxydihydrochalcone 5) 
Briefly, $2 \times 10^{4}$ cells per well were plated in $200 \mu \mathrm{L}$ of medium in 96-well plates and incubated for $24 \mathrm{~h}$. Then, the medium was removed, and fresh growth medium containing different concentrations of the test samples was added to the cells. After $24 \mathrm{~h}$, the growth medium was removed, the MTT reagent $(0.2 \mathrm{mg} / \mathrm{mL})$ was added, and the cells were incubated for $4 \mathrm{~h}$. The medium was then discarded, and the intracellular formazan product was dissolved in $150 \mu \mathrm{L}$ DMSO. The absorbance of each well was measured at $570 \mathrm{~nm}$ using an ELISA reader. Cell viability was expressed as a percentage of the cell viability of control cells.

HSCCC Separation. The selection of the two-phase solvent system was conducted according to the partition coefficient $(K)$ of the target compounds. In the present study, the $K$ value was determined by HPLC as follows. The crude sample powder was dissolved into an appropriate amount of a pre-equilibrated two-phase solvent system and placed into a separation funnel. The funnel was shaken vigorously to equilibrate the sample between the two phases. Then, $2 \mathrm{~mL}$ of each phase was evaporated to dryness. The residue was dissolved in $1 \mathrm{~mL}$ of methanol and subsequently analyzed by HPLC. The $K$ value was defined as the peak area of component in the upper phase divided by the peak area of component in the lower phase.

The two-phase solvent system used here was composed of hexane-ethyl acetate-methanol-water (10:4:10:10, $v / v / v / v)$. Each solvent was added to a separation funnel and thoroughly equilibrated at room temperature. The upper phase and lower phase were then separated and degassed via ultrasonic bath for $30 \mathrm{~min}$ before use. Sample solutions for HSCCC separation were prepared as follows: $200 \mathrm{mg}$ of the sample was dissolved in $10 \mathrm{~mL}$ of the lower phase.

For each of the separation processes, the column was firstly filled entirely with the lower phase (stationary phase). Then, the mobile phase was pumped into the column at a flow rate of $1.8 \mathrm{~mL} / \mathrm{min}$. This occurred while the apparatus was rotated at $800 \mathrm{rpm}$.

After the solvent front emerged and the system established a steady-state hydrodynamic equilibrium, the sample solution was injected into the separation column. After the sample injection occurred, data were immediately collected. Fractions were collected according to the chromatogram. They were then evaporated under reduced pressure. Residues were dissolved in methanol in preparation for purity analysis by HPLC.

HPLC Analysis and Identification of Compounds. An ODS $\mathrm{C}_{18}$ column $(4.6 \times 250 \mathrm{~mm}, 5 \mu \mathrm{m})$ was used to analyze the sample and each fraction of HSCCC. The HPLC mobile phases were $\mathrm{H}_{2} \mathrm{O}$ for solvent $\mathrm{A}$ and $\mathrm{CH}_{3} \mathrm{OH}$ for solvent $\mathrm{B}$. They were eluted from $60 \% \mathrm{~B}$ to $65 \% \mathrm{~B}$ in $5 \mathrm{~min}$, followed by $75 \% \mathrm{~B}$ in $30 \mathrm{~min}$. The flow rate was $1.0 \mathrm{~mL} / \mathrm{min}$, and the detection wavelength was $254 \mathrm{~nm}$. Figure 3 shows the HPLC analysis of $80 \%$ fraction.

\section{Results and Discussion}

Screening of Anticancer Fraction. In order to find anticancer fraction of $O$. falcata, the anticancer activity was estimated with the MTT test. The anticancer activities of petroleum ether, ethyl acetate, water extract, $20 \%$ ethanol fraction, $40 \%$ ethanol fraction, $60 \%$ ethanol fraction, and $80 \%$ ethanol fraction were evaluated in vitro. The result showed that the $80 \%$ ethanol fraction decreased the viability of SMMC-7721 cells. Based on the anticancer activity, 80\% ethanol fraction was treated by HSCCC to obtain active compounds.

Selection of HSCCC Conditions. A successful HSCCC separation depends on the selection of a suitable two-phase solvent system. The suitability of the system depends on the following conditions [17, 18]: (1) the settling time of the solvent system should be less than $20 \mathrm{~s}$; (2) $K$ of the compound should fall within a suitable range $(0.2<K<5)$; and (3) the separation factor between the 2 compounds should be greater than 1.2.

We optimized the solvent system for HSCCC separation considering the above-stated principles. A series of common solvent systems based on ethyl acetate-methanol-water, $n$-butanol-ethyl acetate-water, and hexane-ethyl acetate-methanol-water were tested by changing the volume ratio of solvents to obtain the optimum conditions that could provide suitable $K$ values. The measured $K$ values are shown in Table 1 . The solvent systems with ethyl acetate-methanol-water and $n$-butanol-ethyl acetate-water were tested first; large $K$ values were obtained. The hexane-ethyl acetate-methanolwater $(10: 10: 10: 10,8: 10: 10: 10$, and $6: 10: 10: 10, v / v / v / v)$ were further studied, it was found that the compounds were mainly
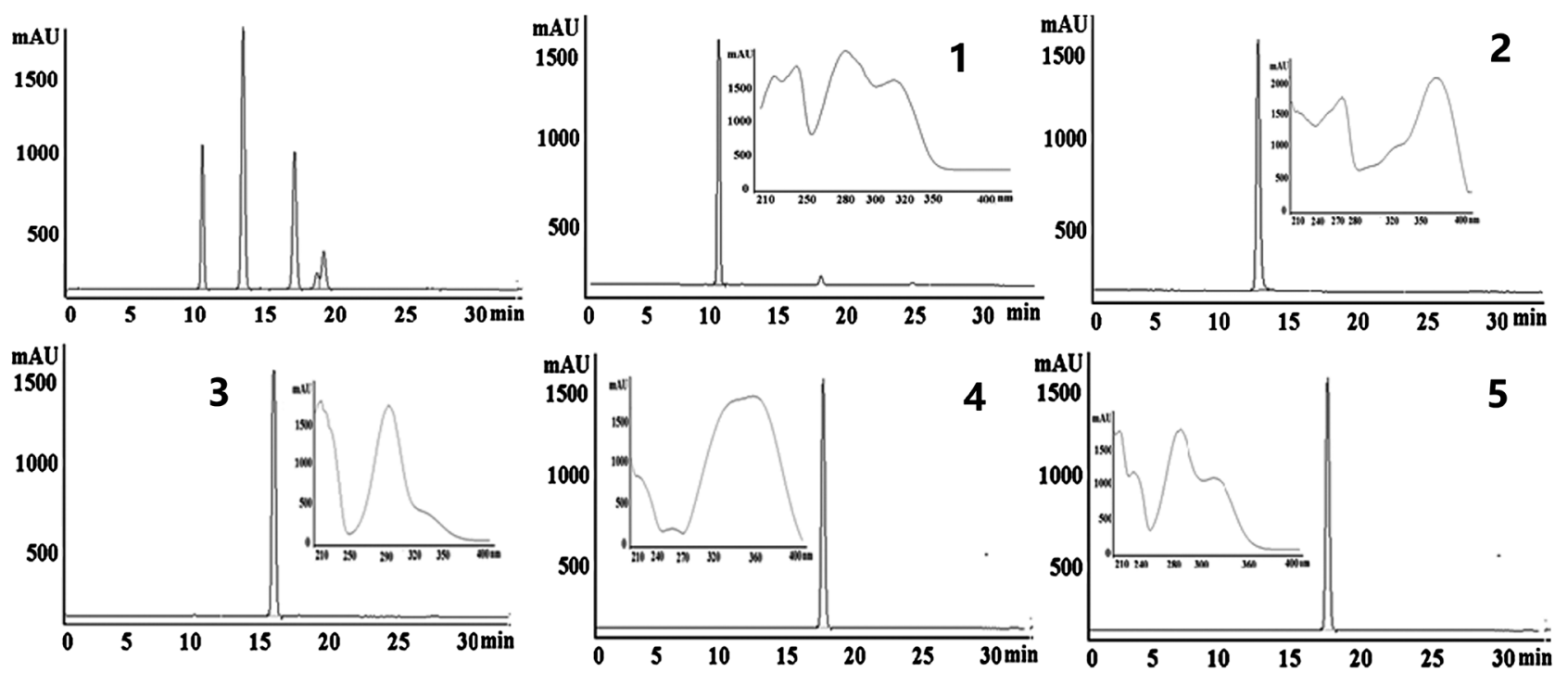

Figure 3. HPLC analysis of $80 \%$ ethanol elution and the compounds 1, 2, 3, 4, and $\mathbf{5}$. Conditions: column, ODS $\mathrm{C}_{18}$ column $(250 \mathrm{~mm} \times 4.6 \mathrm{~mm}$ i.d., $5 \mu \mathrm{m}$ ); column temperature, $25^{\circ} \mathrm{C}$; mobile phase, $\mathrm{H}_{2} \mathrm{O}$ (solvent A) and $\mathrm{CH}_{3} \mathrm{OH}$ (solvent B); HPLC analysis, $0-5$ min, linear gradient from 60 to $65 \% \mathrm{~B}$; 5-35 min, linear gradient from 65 to $75 \% \mathrm{~B}$; flow rate, $1.0 \mathrm{~mL} / \mathrm{min}$; detection wavelength, $254 \mathrm{~nm}$ 
Table 1. The $K$ values of the target compounds in different solvent systems

\begin{tabular}{|c|c|c|c|c|c|c|}
\hline Solvent system & Volume ratio & 1 & 2 & 3 & 4 & 5 \\
\hline ethyl acetate-methanol-water & $4: 1: 5$ & $>5$ & $>5$ & $>5$ & $>5$ & $>5$ \\
\hline$n$-butanol-ethyl acetate-water & $4: 1: 5$ & $>5$ & $>5$ & $>5$ & $>5$ & $>5$ \\
\hline$n$-hexane-ethyl cetate-methanol-water & $10: 10: 10: 10$ & 0.06 & 0.12 & 0.15 & 0.23 & 0.28 \\
\hline$n$-hexane-ethyl acetate-methanol-water & $6: 10: 10: 10$ & 0.18 & 0.28 & 0.32 & 0.41 & 0.40 \\
\hline$n$-hexane-ethyl acetate-methanol-water & $10: 8: 10: 10$ & 0.22 & 0.32 & 0.31 & 0.43 & 0.46 \\
\hline$n$-hexane-ethyl acetate-methanol-water & $10: 6: 10: 10$ & 0.34 & 0.65 & 0.54 & 1.42 & 0.96 \\
\hline$n$-hexane-ethyl acetate-methanol-water & $10: 4: 10: 10$ & 0.41 & 0.89 & 0.60 & 1.79 & 1.26 \\
\hline
\end{tabular}

distributed in one phase, and good results could not be obtained. When the ratio of hexane-ethyl acetate-methanolwater was fixed at 10:8:10:10, and the $K$ of the compound was good, but the separation factor was not good. Therefore, the ratio of ethyl acetate was decreased, and when the ratio of hexane-ethyl acetate-methanol-water was fixed at 10:4:10:10, the $K$ of the compounds and the separation factor were good. After consideration, the solvent system of hexane-ethyl acetate-methanol-water $(10: 4: 10: 10, v / v / v / v)$ was finally selected for the HSCCC separation.

Under the optimized conditions, good separation results were obtained (Figure 4). In only one round of HSCCC separation, 5 fractions (A-E) were obtained in $260 \mathrm{~min}: 32.7 \mathrm{mg}$ A, $34.9 \mathrm{mg} \mathrm{B}, 28.5 \mathrm{mg} \mathrm{C}, 26.7 \mathrm{mg} \mathrm{D}$, and $22.6 \mathrm{mg}$ E. The HPLC analysis of each fractions revealed that the purities of these 5 compounds (1-5) were 97.7\%, 98.1\%, 98.3\%, 99.0\%, and $98.3 \%$, respectively (Figure 3 ).

Structural Identification. The chemical structures of the separated compounds were identified according to their ${ }^{1} \mathrm{H}$ and ${ }^{13} \mathrm{C}$ NMR spectra and compared with the literature data. The compounds were identified as follows.

Fraction A: 7-hydroxyflavonone 1, $\mathrm{C}_{15} \mathrm{H}_{10} \mathrm{O}_{4},{ }^{1} \mathrm{H}$ NMR $\left(500 \mathrm{MHz}, \mathrm{CD}_{3} \mathrm{OD}\right) \delta 7.73(1 \mathrm{H}, \mathrm{d}, J=8.7 \mathrm{~Hz}, \mathrm{H}-4), 7.49$ $\left(2 \mathrm{H}, \mathrm{d}, J=7.5 \mathrm{~Hz}, \mathrm{H}-2^{\prime}, 6^{\prime}\right), 7.40\left(2 \mathrm{H}, \mathrm{t}, J=7.5 \mathrm{~Hz}, \mathrm{H}-3^{\prime}, 5^{\prime}\right)$, $7.35\left(1 \mathrm{H}, \mathrm{d}, J=7.5 \mathrm{~Hz}, \mathrm{H}-4^{\prime}\right), 6.51(1 \mathrm{H}, \mathrm{dd}, J=8.7,1.6 \mathrm{~Hz}$, H-6), $6.39(1 \mathrm{H}, \mathrm{d}, J=1.6 \mathrm{~Hz}, \mathrm{H}-8), 5.48(1 \mathrm{H}, \mathrm{dd}, J=12.9$, $2.3 \mathrm{~Hz}, \mathrm{H}-2), 3.02(1 \mathrm{H}, \mathrm{dd}, J=16.8,13.0 \mathrm{~Hz}, \mathrm{H}-3 \mathrm{a}), 2.75$ $(1 \mathrm{H}, \mathrm{dd}, J=16.8,2.7 \mathrm{~Hz}, \mathrm{H}-3 \mathrm{~b}) ;{ }^{13} \mathrm{C} \mathrm{NMR}(151 \mathrm{MHz}$, $\left.\mathrm{CD}_{3} \mathrm{OD}\right) \delta 193.0$ (C-4), 166.8(C-7), 165.4 (C-8a), 140.7 (C$\left.1^{\prime}\right), 129.9\left(\mathrm{C}-3^{\prime}, 5^{\prime}\right), 129.7\left(\mathrm{C}-4^{\prime}\right), 129.6(\mathrm{C}-5), 127.3\left(\mathrm{C}-2^{\prime}, 6^{\prime}\right)$, 115.0 (C-4a), 111.9 (C-6), 103.8 (C-8), 81.0 (C-2), 45.1 (C-3).
Compared with the reported data, the ${ }^{1} \mathrm{H}$ NMR and ${ }^{13} \mathrm{C}$ NMR data are in agreement with that of 7-hydroxyflavonone in the literature [19].

Fraction B: 5,7-dihydroxy-4'-methoxy flavonol 2, $\mathrm{C}_{15} \mathrm{H}_{10} \mathrm{O}_{4},{ }^{1} \mathrm{H}$ NMR $\left(500 \mathrm{MHz}, \mathrm{CD}_{3} \mathrm{OD}\right) \delta 8.02(2 \mathrm{H}, \mathrm{d}$, $\left.J=8.5 \mathrm{~Hz}, \mathrm{H}-2^{\prime}, 6^{\prime}\right), 6.81\left(2 \mathrm{H}, \mathrm{d}, J=8.5 \mathrm{~Hz}, \mathrm{H}-3^{\prime}, 5^{\prime}\right), 6.49$ $(1 \mathrm{H}, \mathrm{s}, \mathrm{H}-6), 6.20(1 \mathrm{H}, \mathrm{s}, \mathrm{H}-8), 3.81\left(3 \mathrm{H}, \mathrm{s},-\mathrm{OCH}_{3}\right) ; 13 \mathrm{C}$ NMR (151 MHz, CD 3 OD) $\delta 177.5$ (C-4), 167.0 (C-7), 162.2 (C-5), 160.7 (C-4'), 158.2 (C-8a), 146.9 (C-2), 137.5 (C-3), 130.8 (C-2',6'), 123.6 (C-1'), 116.3 (C-3',5'), 105.4 (C-4a), 98.6 (C-6), 95.7 (C-8), 92.71, $56.4\left(-\mathrm{OCH}_{3}\right)$. Compared with the reported data, the ${ }^{1} \mathrm{H}$ NMR and ${ }^{13} \mathrm{C}$ NMR data are in agreement with that of 5,7-dihydroxy-4'-methoxy flavonol in the literature [20].

Fraction C: 5,7-dihydroxyflavanone $3, \mathrm{C}_{15} \mathrm{H}_{12} \mathrm{O}_{4},{ }^{1} \mathrm{H}$ NMR (500 MHz, CD $\left.{ }_{3} \mathrm{OD}\right) \delta 7.44\left(2 \mathrm{H}, \mathrm{d}, J=7.4 \mathrm{~Hz}, \mathrm{H}-2^{\prime}, 6^{\prime}\right), 7.36$ $\left(2 \mathrm{H}, \mathrm{t}, J=7.4 \mathrm{~Hz}, \mathrm{H}-3^{\prime}, 5^{\prime}\right), 7.32\left(2 \mathrm{H}, \mathrm{t}, J=7.4 \mathrm{~Hz}, \mathrm{H}-4^{\prime}\right)$, $5.89(1 \mathrm{H}, \mathrm{s}, \mathrm{H}-6), 5.86(1 \mathrm{H}, \mathrm{s}, \mathrm{H}-8), 5.39(1 \mathrm{H}, \mathrm{dd}, J=12.6$, $3.6 \mathrm{~Hz}, \mathrm{H}-2), 3.03(1 \mathrm{H}, \mathrm{dd}, J=17.0,12.6 \mathrm{~Hz}, \mathrm{H}-3 \mathrm{a}), 2.71$ $(1 \mathrm{H}, \mathrm{dd}, J=17.0,2.6 \mathrm{~Hz}, \mathrm{H}-3 \mathrm{~b}) ;{ }^{13} \mathrm{C} \mathrm{NMR}(151 \mathrm{MHz}$, $\left.\mathrm{CD}_{3} \mathrm{OD}\right) \delta 197.2$ (C-4), 168.8 (C-7), 165.5 (C-5), 164.6 (C8a), $140.4\left(\mathrm{C}-1^{\prime}\right), 129.7$ (C-2',6'), 129.6 (C-4'), 127.3 (C-3',5'), 103.2 (C-4a), 97.2 (C-6), 96.3 (C-8), 80.4 (C-2), 44.1 (C-3). Compared with the reported data, the ${ }^{1} \mathrm{H}$ NMR and ${ }^{13} \mathrm{C}$ NMR data are in agreement with that of 5, 7-dihydroxyflavanone in the literature [21].

Fraction D: 2',4' -dihydroxychalcone $4, \mathrm{C}_{15} \mathrm{H}_{11} \mathrm{O}_{3},{ }^{1} \mathrm{H}$ NMR $\left(500 \mathrm{MHz}, \mathrm{CD}_{3} \mathrm{OD}\right) \delta 7.88(1 \mathrm{H}, \mathrm{d}, J=8.9 \mathrm{~Hz}, \mathrm{H}-9)$, $7.71(2 \mathrm{H}, \mathrm{m}, \mathrm{H}-1,2), 7.32\left(2 \mathrm{H}, \mathrm{d}, J=6.7 \mathrm{~Hz}, \mathrm{H}-2^{\prime}, 6^{\prime}\right), 7.33$ $\left(3 \mathrm{H}, \mathrm{m}, \mathrm{H}-3^{\prime}, 4^{\prime}, 5^{\prime}\right), 6.32(1 \mathrm{H}, \mathrm{dd}, J=8.7,1.5 \mathrm{~Hz}, \mathrm{H}-8), 6.18$ $(1 \mathrm{H}, \mathrm{d}, J=1.5 \mathrm{~Hz}, \mathrm{H}-6) ;{ }^{13} \mathrm{C}$ NMR $\left(151 \mathrm{MHz}, \mathrm{CD}_{3} \mathrm{OD}\right) \delta$

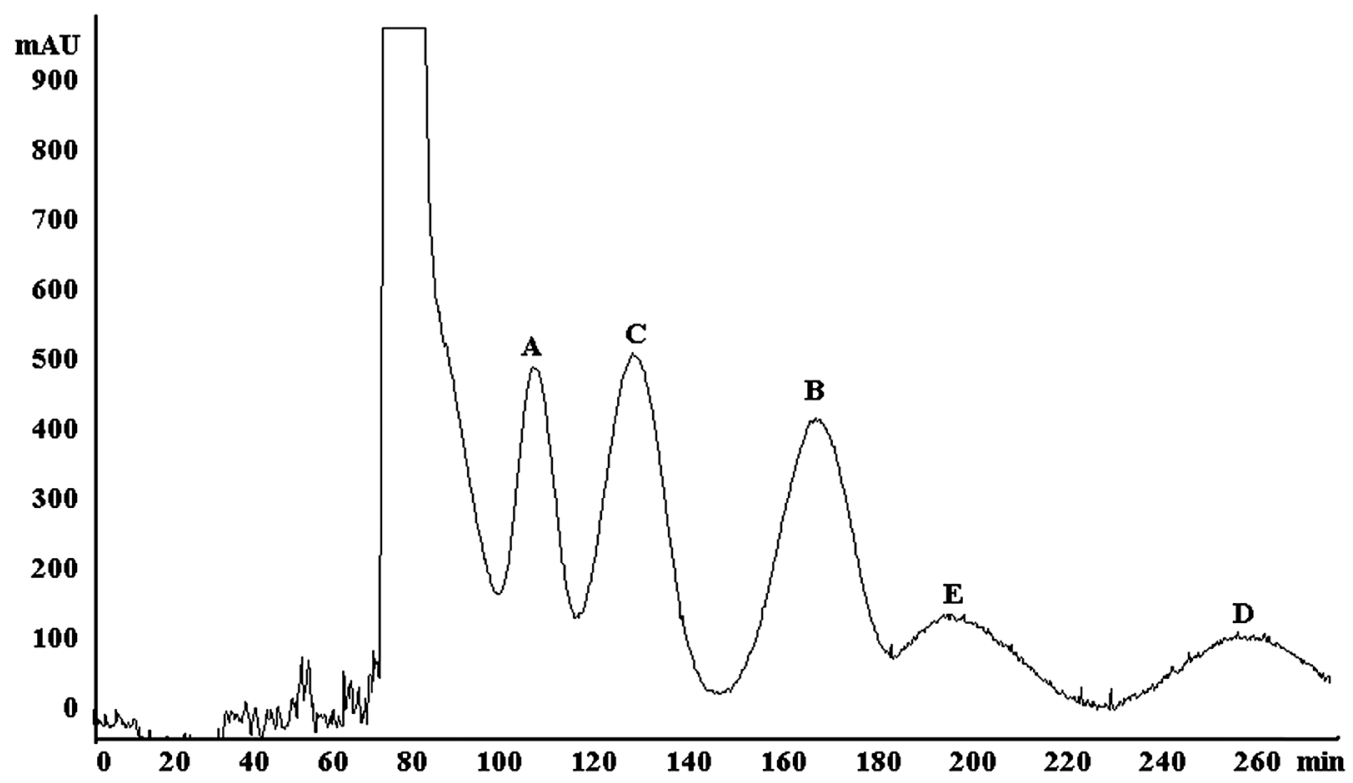

Figure 4. HSCCC chromatogram of $80 \%$ ethanol elution using the $n$-hexane-ethyl acetate-methanol-water solvent system with a volume ratio of 10:4:10:10. Conditions: stationary phase, upper phase; flow rate, $1.8 \mathrm{~mL} / \mathrm{min}$; revolution speed, $800 \mathrm{rpm}$; detection wavelength, $254 \mathrm{~nm}$; retention of the stationary phase, $62 \%$ 
193.1 (C-3), 167.8 (C-5), 167.7 (C-7), 144.9 (C-1), 136.4 (C$\left.1^{\prime}\right), 133.6$ (C-9), $131.6\left(\mathrm{C}-4^{\prime}\right), 130.0\left(\mathrm{C}-\left(\mathrm{C}-2^{\prime}, 6^{\prime}\right), 129.6(\mathrm{C}-\right.$ 3',5'), 121.9 (C-2), 114.4 (C-4), 109.7(C-8), 103.9 (C-6). Compared with the reported data, the ${ }^{1} \mathrm{H}$ NMR and ${ }^{13} \mathrm{C}$ NMR data are in agreement with that of $2^{\prime}, 4^{\prime}$-dihydroxychalcone in the literature [10].

Fraction E: 2',4'-dihydroxydihydrochalcone 5, $\mathrm{C}_{15} \mathrm{H}_{13} \mathrm{O}_{3}$, ${ }^{1} \mathrm{H}$ NMR (500 MHz, CD $\left.\mathrm{OD}\right) \delta 7.61(1 \mathrm{H}, \mathrm{d}, J=8.8 \mathrm{~Hz}, \mathrm{H}-$ 9), $7.16\left(4 \mathrm{H}, \mathrm{m}, \mathrm{H}-2^{\prime}, 3^{\prime}, 5^{\prime}, 6^{\prime}\right), 7.06\left(1 \mathrm{H}, \mathrm{m}, \mathrm{H}-4^{\prime}\right), 6.23(1 \mathrm{H}$, $\mathrm{dd}, J=8.8,1.9 \mathrm{~Hz}, \mathrm{H}-8), 6.14(1 \mathrm{H}, \mathrm{d}, J=1.9 \mathrm{~Hz}, \mathrm{H}-6), 3.13$ $(2 \mathrm{H}, \mathrm{t}, J=7.6 \mathrm{~Hz}, \mathrm{H}-1), 2.90(2 \mathrm{H}, \mathrm{t}, J=7.6 \mathrm{~Hz}, \mathrm{H}-2) ;{ }^{13} \mathrm{C}$ NMR (151 MHz, CD $\left.{ }_{3} \mathrm{OD}\right) \delta 205.2$ (C-3), 166.4 (C-5), 166.4 (C-7), 142.5 (C-1'), 133.6 (C-8), 129.4 (C-3',4',5'), 127.1 (2',6'), 114.0 (C-4), 109.1 (C-7), 103.6 (C-6), 40.5 (C-2), 31.6 (C-1). Compared with the reported data, the ${ }^{1} \mathrm{H}$ NMR and ${ }^{13} \mathrm{C}$ NMR data are in agreement with that of 2', 4'-dihydroxychalcone in the literature [22].

Anticancer Activities of Compounds. All compounds exhibited dose-dependent activities. The $\mathrm{IC}_{50}$ values were $213.45 \mu \mathrm{g} / \mathrm{mL}, 197.74 \mu \mathrm{g} / \mathrm{mL}, 375.16 \mu \mathrm{g} / \mathrm{mL}, 17.44 \mu \mathrm{g} / \mathrm{mL}$, and $136.83 \mu \mathrm{g} / \mathrm{mL}$ for compounds $\mathbf{1}-\mathbf{5}$, respectively. Compounds $\mathbf{4}$ and $\mathbf{5}$ exhibited the higher anticancer activities against the cancer cells compared to the positive control $(p<0.05)$. In this study, 5 compounds isolated from $O$. falcata showed notable anticancer activities, which strongly demonstrated that all these compounds may be partially responsible for $O$. falcata's anticancer activity [6-8].

\section{Conclusions}

In summary, the HSCCC experiment was successfully developed for fast isolation and purification of anticancer compounds from $80 \%$ fraction of extract from O. falcata. Five flavonoids, namely, 7-hydroxyflavonone 1, 5,7-dihydroxy-4'methoxy flavonol 2, 5,7-dihydroxyflavanone 3, 2',4'-dihydroxychalcone 4 , and $2^{\prime}, 4^{\prime}$-dihydroxydihydrochalcone $\mathbf{5}$, were isolated and identified. The isolated flavonoids were evaluated for their anticancer activity, and all compounds showed anticancer activity against the growth of SMMC-7721 cells. The results of the present study indicated that these compounds are worth further investigating.

\section{Conflicts of Interest}

The authors declare that there are no conflicts of interest regarding the publication of this paper.

Acknowledgements. This work was supported by the Application Basic Research Programs of Qinghai Province (2015-ZI-729) and CAS Key Technology Talent Program.

\section{References}

1. Luo, D. S. China traditional Tibetan herbal, Nation press, Beijing 1997, pp 325-326.

2. Yang, G. M.; Wang, D.; Tang, W.; Chen, X.; Fan, L. Q.; Zhang, F. F.; Yang, H.; Cai, B. C. Chin. J. Natur. Med. 2010, 8, 285-292.

3. Dai, X. P.; Zhang, G. H.; Ban, C. H.; Guan, X. M. Chin. J. Bio. Phar. 2010, 31, 313-315.

4. Wang, D.; Yang, H.; Li, D.; Cai, B. C. Phar. Clin. Res. 2008, 16, 90-93. 5. Zhang, F. F.; Yang, G. M.; Wang, D.; Wang, M. Y.; Cai, B. C. Phar. Clin. Res. 2010, 18, 135-138.

6. Yang, G. M.; Yan, H.; Gu, Q.; Li, J. S.; Pan, Y.; Cai, B. C. Chin. Phar. J. 2013, 48, 2113-2116.

7. Yang, G. M.; Zhang, F. F.; Wang, D.; He, Y. Y.; Tong, L.; Cai, B. C. Chi. J. Chin. Mater. Med. 2011, 36, 1227-1230.

8. Chen, X. H.; Cheng, H. Q.; Deng, Y.; Yang, G. M.; Pan, Y. J. Nanjing Uni. Tradi. Chin. Med. 2017, 31, 54-58.

9. Que, S.; Zhang, Y. S.; Zhao, Y. Y. Chin. Trad. Herb. Drugs 2007, 38, $1458-1460$

10. Lv, F.; Xu, Y. J. Chin. J. Chin. Mate. Med., 2007, 32, 318-320.

11. Wang, W. D.; Tao, Y. D.; Jiao, L. J.; Fan, M. X.; Shao, Y.; Wang,

Q. L.; Mei, L. J.; Dang, J. J Sep. Sci. 2017, 40, 3593-3601.

12. Ito, Y.; Conway, W. D. Ana. Chem. 1984, 56, 534-554.

13. Walasek, M.; Grzegorcyk, A.; Malm, A.; Skalicka-wozniak, K. Food Chem. 2015, 186, 133-138.

14. Mao, Q.; Yang, J.; Cui, X. M. J. Phar. Bio. Anal. 2012, 59, 67-77.

15. Chen, C.; Chen, T.; Liu, Y. L.; Zou, D. L.; You, J. M.; Li, Y. L. Sep.

Sci. Tec., 2015, 50, 604-610.

16. Mosmann, T. J. Immunl. Meth. 1983, 65, 55-63.

17. Yue, H. L.; Zhao, X. H.; Wang, Q. L.; Tao, Y. D. J. Chro. B 2013, 936 , $57-62$.

18. Shi, J. Y.; Li, G. L.; Wang, H. L.; Zheng, J.; Suo, Y. R.; You, J. M.; Liu, Y. L. Phyto. Anal. 2011, 22, 450-454

19. Hsin, K. H.; Tai, H. L.; Jih, P. W.; Lin, C. N. Phar. Res. 1998, 15, $39-46$.

20. Li, Q.; Shen, Y. M.; Li, P. Chin. Phar. J. 2008, 43, 417-419.

21. Katerere, D. R.; Gray, A. I.; Nash, R. J. Waigh, R. D. Fito. 2012, 83, 932-940.

22. Krasnov, E. A.; Ermilova, E. V.; Kadyrova, T. V.; Raldugin, V. A.; Bagryanskaya, I. Y.; Gatilov, Y. V.; Druganow, A. G.; Semenov, A. A.; Tolstikov, G. A. Chem. of Natu. Com. 2000, 36, 493-496. 